\title{
Rethinking the 'Arab Spring': The Root Causes of the Tunisian Jasmine Revolution and Egyptian January 25 Revolution
}

\author{
MOHD IRWAN SYAZLI SAIDIN ${ }^{1}$
}

\begin{abstract}
This article reviews the events of 2010-2011 Tunisian and Egyptian revolutions with specific attention to the background of uprisings, timeline of events and causes of the revolutions. The focus of this study is to look into the factors that ignited the revolutions, both in Tunisia and Egypt. By examining secondary sources mainly through published reports dan journal articles, it will highlight how the uprisings in Tunisia and Egypt evolved besides shedding light on the 2011 Arab Spring event. A number of factors have been selected under five main themes namely economics development, political legitimacy, social demography, Islamism and the advance of new social media. All these factors, to large extent have contributed to the causes of this popular uprisings which led to the collapse of the previous regime of Ben Ali and Hosni Mubarak. Among these factors, the role of new social media was identified as the main factor which secure the successful of the revolutions in Tunisia and Egypt and considered as a new platform of political protest in the Middle East and North Africa.
\end{abstract}

Keywords: Arab Spring, Egypt, revolution, social media, Tunisia

Nearly seven years ago, the act of massive civil resistance had shaken the region of the Middle East and North Africa more than one could ever imagine. It tragically originated in Tunisia on December 17, 2010 when Mohamed Bouazizi, a street vendor set himself on fire in protest of the brutality treatment and injustice he received from the government officials. His death later on turned into enormous demonstrations, from one country to another until the entire region was engulfed, leading to a new era in the history of the region known as the 'Arab Spring' (Moaddel 2012: 3). The next month, the majority of Egyptians in Cairo went to the Tahrir Square to organize a rally to fight against the brutality of the forces, government corruption and economic depression, an action that led to the overthrow of President Hosni Mubarak. These revolutions came in the form of a longawaited civil uprising mainly of Arab youths in the Middle East, an effort to give rise to the democratic wave in the region. The 2011 Arab Spring event, by no doubt is considered one of the most remarkable events in the 21st century. Besides the tragedy of Bouazizi's death as well as the so called 'domino' effect from Tunisia, the question arises; what really sparked the Tunisians and Egyptian to take to the street and topple their governments? The following section will discuss in further detail the case of Tunisia's Jasmine Revolution and the Egyptian Uprising, with specific attention to the background to revolutions, timeline of events and causes of the revolutions. A number of factors have been selected under five main themes namely economics development, political legitimacy, social demography, Islamism and the advance of new social media. All these factors, to large extent have contributed to the causes of this popular uprisings which led to the collapse of the previous regime of Ben Ali and Hosni Mubarak. Among these factors, the role of new social media was identified as the main factors which secure the successful of the revolution and considered as a new form of political protest in the Arab world.

\footnotetext{
${ }^{1}$ Mohd Irwan Syazli Saidin, Ph.D. candidate, the Institute of Arab and Islamic Studies, College of Social Sciences and International Studies, University of Exeter, Stocker Road, EXETER EX4 4ND, United Kingdom, email: irwansyazli@ukm.edu.my.
} 


\section{The Case of 2010-2011 Tunisia's Jasmine Revolution}

For the first time in the Tunisian history, on January 14, 2011, the regime of President Zine El Abidine Ben Ali collapsed and as the result, fled the country to Saudi Arabia, for political asylum following weeks of popular revolt and anti-government protests. After more than two decades of silence and fear, the Tunisians had finally dared to do the unthinkable. Indeed, only a week earlier no one had imagined that the 'royal' escape would become reality. His departure was greeted by widespread euphoria within the country (Arieff 2012). According to Gelvin (2012: 44), this event marked its first time in the modern history of the Arab world when a popular uprising forced the ouster of a ruler. Ben Ali was clearly asked to "Go Away" and was told that the "Game is Over". Tunisia's mass awakening, dubbed the 'Jasmine Revolution' appeared to have added timely momentum and boosted the moral of Tunisian youth to fight against Ben Ali regime and raised proreform and anti-government sentiments across the Arab region. Inevitably, as claimed by Arieff (2012), Tunisia is viewed as an important test case for democratic transitions elsewhere in the Middle East. The protesters demands were very straightforward, translated into provision of jobs and economic opportunity, political freedom and self-dignity. Like all revolutions, the Tunisian revolution was not an overnight event but rather a long process which was caused by a few factors and acted by a number of actors, mainly the Tunisian youth. This revolution has clearly constituted a real political surprise inside, as well as outside the country (Ayeb 2011: 467).

\section{Timeline of Event: The December 2010-January 2011 Protests}

The Jasmine Revolution was first reported on 17 December 2010, triggered by an individual act- the self-immolation of the young Mohamed Bouazizi-followed by a local reaction in the city of Sidi Bouzid, North East of Tunisia. This 26-year old street vendor set himself on fire to protest police interference and the lack of economic opportunities. He died in Tunis hospital on January 5, 2011 after suffering from 90 percent burns all over his body. Within days of Bouazizi's attempted suicide in front of the local government office, the majority of Tunisians including students, teachers, lawyers, journalists, human rights activists, trade unionists, and opposition politicians took to the streets in several cities, including Tunis, to condemn the government's economic policies, its repression off all critics, and a mafia-style corruption that had endowed power and money to members of Ben Ali's family (Alexander 2011). According to Alexis Arieff (2012: 90), in Tunisia, public demonstrations had previously been very rare since the state repression had traditionally been effective at curbing anti-government actions. Surprisingly, an anti-government protest was launched in mid-December 2010. The demonstrations initially seemed to have stemmed from the mass discontent related to high unemployment, but it quickly spiraled into an unprecedented popular challenge to Ben Ali regime. By late December, the protest had spread to the nearby cities of Kasserine and Thala, as well as other urban centers. Beginning in an underprivileged region, which had been neglected by the development efforts witnessed in other regions, the uprising subsequently spread to the rest of the country (Ahmed Driss 2012: 22). After nearly two weeks of protests, president Ben Ali had been broadcast on national television, promising actions on more job creation and economic stability, however, all these efforts had seemed too late for him to remain in power.

On January 12, riots erupted in the Capital of Tunis which brought the state into chaos and mass revolution (Arieff 2012: 9). Moreover, the situation became worse when the military was deployed to the streets and a national curfew was imposed. On the next several days, on January 13, Ben Ali once again had addressed his people on the state television in which he pledged to step down from his position after the ruling term finishes in 2014 and gave a promise that he would not be involve in the next presidential election. However, these promises did not placate the demonstrators, who continued to press for his immediate resignation and the dissolution of the ruling party. Following the uncertainty across the country, authorities imposed a state of emergency 
on January 14, prohibiting gatherings of over three people and authorizing the use of force against 'brutal' protesters. On the same day, Ben Ali, his wife Leila Trebelsi, their five year old son, one of his daughters and her fiancé fled to the airport, an action which finally validated his escape to Saudi Arabia. As protest, mass mobilization, demonstration and revolution mounted in mid-December and early January, the police repeatedly opened fire on crowds and arrested protesters, journalists, opposition party members, lawyers and rights advocates. Some detainees were reportedly tortured and over 200 people killed in the uprising (Arieff 2012: 10-12). Whatever the consequences that came out from this civil resistance, the Tunisia's Jasmine Revolution is vital for political transition and carves the history of Tunisia's democratization as it has never experienced a democratic transition power through the ballot box.

\section{Major Causes of The Tunisia's Jasmine Revolution}

For Tunisians, 23 years living under Ben Ali's dictatorship regime, has managed to successfully expose to the world that there are other deep rooted factors, far beyond Bouazizi's tragedy, that have caused the revolution. This article shall put forth the argument that there are five main issues which have contributed to the Tunisian uprising.

\section{Economic Crisis}

According the March 2011 report from National Lawyers Guild (US), Haldane Society of Socialist Lawyers (UK) and Mazlumder (Turkey), the Tunisian revolutionaries were spurred on to take to the streets by endemic poverty, rising food prices, and chronic unemployment. Despite its economic growth and macroeconomic performance in the early 2000s, however, Tunisia is a complex case, with a delicate authoritarian bargain taking place between the regime and society. For a long time, the regime was able to provide economic and social gains to large sentiments of the population and secure its legitimacy and political stability in return. The authoritarian bargain however, had broken down due to the growing inability of the economy to create jobs for the educated labor, the proliferation of poorly paid jobs in the informal sector, and the rising income inequality and regional disparities (Achy 2011: 5). In fact, the European recession in 2009 affected the Tunisian economy, producing a decrease in exports and lower expansion in services (Arieff 2012: 34). The Euro-zone crisis continued to exacerbate in 2010 which further declined the tourism revenues and closed down both local and foreign businesses as the international credit crunch continued. Prior to the revolution, the unemployment crisis in Tunisia has claimed its victims for several years, mainly among youth and university graduates due to the economic instability (Haouas et al 2012). This statement is supported by Driss (2011: 21-22) by showing the impact of the economic crisis which led to the revolt against the regime. The decline in the spending power, rising prices, growing household debt, high levels of unemployment, particularly youth unemployment (23\%) and young graduate unemployment (37\%) were among the problems faced by Tunisians as a result of bad economic policies. Moreover, for young graduates, unemployment is generally very badly lived plus the feeling of injustice, coupled with their view that very often jobs are assigned in a transparent manner, and that corruption and favoritism are the determining factors in obtaining work. It has become something far from surprising when Tsai (2012: 187) claims that high unemployment has been a consistent problem in Tunisia for over twenty years. As Driss (2011) has pointed out, these factors were, without dispute, the motors of the protest movement in Tunisia that led the regime to fall. Economic grievances, with unemployment at the forefront, were at the heart of the revolution (Chang 2012: 175).

Political Legitimacy 
Since Ben Ali's rise to power in 1987, Tunisia's counterfeit stability has been ensured at the cost of deep political regression. Over the years, the country became home to one of the most repressive and authoritarian regimes in the region, which declined Ben Ali's political legitimacy until 14 January 2011. The regime seems to have a systematic political repression through widespread violation of human rights, corruption at various levels and the lack of political freedom (Ayadi et. al. 2011: 2). As claimed by Ayeb (2011: 468), Tunisia had the kind of absolute dictatorship with a modernist face. He argues that the first cause of the fall of Ben Ali regime was its brutal ruling nature. All potential spaces for expression such as the media, research centers and civil society organisations were closed down during his era. Meanwhile, Bishara has pointed out that Tunisia was a regime which left no space for persons or entities to mediate between the people and the state. The role of security apparatus was excellent in securing Ben Ali regime from any public disobedient and resistance including from the members of the opposition parties. There was no freedom of press. The few political parties that were tolerated would not have been tolerated if they had gathered more than three per cent of the votes. The regime not only refused to respect human and civil rights, but it also used forces to systematically trample them (Bishara 2011: 5).

The 'political police', officially the State Security Department serves as the enforcers of Ben Ali's doctrine of political legitimacy. As reported by Machado (2012: 155), the methods of political police were like those of the mafia, but imbued with the resources and authority of a nationkidnapping, blackmail, even torture and most likely murder - the probable fate of the many political prisoners who 'disappeared' over the years. Apart from that, one of the issues concerning political legitimacy during the revolution was the extreme arrogance of Ben Ali, his family and his government. Ben Ali himself started to become increasingly out of touch, was being hostile to criticisms and more close-minded, as some had noted, in the beginning of 2005. All political decisions were made by him. Besides that, one of the main fuels for the anti-government anger was the nepotism practised by his family particularly his wife, Leila Trabelsi. The members of the 'Trabelsi clan' held a major share of assets in the country in all sectors of the economy ranging from bank, insurance, distribution, transport, tourism and property. According to El-May (2012: 57), in the 23 years of Ben Ali's rule, his family stole at least two percent of the Tunisian growth. This over centralization and abuse of power mean that the state legitimacy had declined considerably thus, opening the space for mass revolution against dictatorship as occurred in the previous waves of democratization in several European and South American states back in the 1970-1990s. The fact that tens of thousands of Tunisians were driven into the streets to express their grievances, revealed the extent to which the Tunisian population no longer felt that their formal political system was responsive to their demands (Hamblin 2012: 93).

\section{The Role of Youth and Civil Society Groups}

The majority of Tunisians who took to the streets were young, unemployed and underemployed graduates who were disillusioned with the government. Many of them have completed higher education but were still unable to find work. The role of young Tunisians were extremely significant in the overthrow of the Ben Ali regime as they united together to express their solidarity with Bouazizi's death and to protest against the economic hardship and youth unemployment (Howana 2011: 2). It is therefore, worth understanding that one of the greatest concerns of the youth from this revolution was seeking for justice, for Bouazizi, their friends, family members and for the whole nation. According to Marzuki et al (2012: 238), the Tunisian revolution was fully and spontaneously driven by the youth who were the only actors on the stage during the uprisings. Besides that, civil society groups composed of teachers, journalists, lawyers and trade unions had well supported the youth in the demonstrations. According to Honwana (2011: 13), the participation of Tunisian General Labour Union (UGTT) and the Bar Association helped form a broader national coalition against the regime. At this point, the youth revolt was transformed into a revolution as the demands 
widened from a solution to socioeconomic grievances to regime change and they successfully managed to end Ben Ali's career. Year 2011, by no doubt was the year of a global youth revolt.

Islamism

Tunisia, after gaining independence from France in 1956 declared itself as a secular state under Ben Ali's predecessor, Habib Bourguiba. Although the vast majority of the population are Muslims, the government never acknowledges Islam as the state's official religion. The Tunisian government is rooted in the secular Arab nationalist ideology (Ba'athism) and has long taken its secularism more seriously (Koplow 2011). According to Arieff (2012: 22), Islamists did not play a prominent role in the protest that had unseated Ben Ali. By the time the revolution began, the Islamists were unable to meet or organize, but they were present in other civil society organizations like the unions, professional groups and human rights activities which managed to survive, if not to flourish. He also adds that those Islamists in Tunisia were not just Islamists since some of them were doctors, teachers, journalist or lawyers. They work alongside the nationalists, secularists and the socialists in every walk of life (Noueihed \& Warren 2012: 68). As Koplow (2011) demonstrates, the main challenge to the Tunisian regime came not from the Islamist opposition but from the secular intellectuals. The absence of a strong Islamist was the result of an aggressive attempt by the Tunisian regimes, dating back a half century, to eliminate Islamists from public life. The Islamist group thought to be Tunisia's largest was the formerly banned party, Ennahda, led by Rachid Ghannouchi. Thousands of suspected Islamists and Ennahda members were detained during Ben Ali's presidency and were subjected to various forms of torture. Just like Bourguiba, Ben Ali routinely emphasized the threat of Islamist extremism in order to justify his authoritarian rule (Ariff 2012: 21-22). This history of repressive and discrimination towards Islamists and particularly Ennahda is vital to understand why the Jasmine Revolution was successful in ousting Ben Ali regime without the obvious involvement of the Islamists. Although the protesters represented a threat to the regime, it seemed that they had not directly challenged the reigning creed of the state secularism. If it had been clear that Islamist opposition figures were playing a massive role in the revolution, the regime would likely have doubled down on repressive measures, an action which could fail the Jasmine Revolution altogether (Koplow 2011). Thus, one might say that the insignificant role of Islamist groups during the revolution significantly led to the success of overthrowing Ben Ali regime and marked the beginning of the political transition in Tunisia.

\section{The Advance of New Social Media}

Tunisia was the first Arab countries to have the link to the Internet in 1991 on an experimental level and to allow it on a probationary period (El Gody 2007: 213). Since 1995, Tunisia has interfered with various digital networks for political reasons more times than any other country. During Ben Ali's era, it is very common to see the Internet censorship and the famous web error message 404 Not Found- an action by the authorities to ban any websites or blogs that can potentially, or are suspected to, publish criticisms and sabotage the regime. As Ahmed El Gody (2007: 224) has pointed out, Tunisia has developed the region's most detailed Internet-specific laws, besides explicitly extending the Internet's existing press laws which limit free expression. In Tunisia, between 2000 and 2006, statistics has shown that there were 36 censorship cases occurred, the second highest rank after Iran and in April 2010, the government banned more than 100 blogs as well as other websites (El Gody 2007: 223; Honwana 2011: 9). As Honwana claims, the Tunisian regime selectively targeted and blocked websites and intimidated bloggers who disseminated information against the regime. In other words, political freedom in Tunisia was muffled by the banning participation of political opponents and by practicing internet censorship (Marzuki 2012: 238). 
However, the recent growth of new social media such as Facebook, Twitter, YouTube, Weblogs, WikiLeaks, plus some foreign news agencies such as Al-Jazeera, Russia Today, BBC and CNN, much of them based outside the country-made it increasingly easy for Tunisians inside and outside the country to get alternative sources about latest political issues, the regime's corruption and any information not shown, or even endorsed to be shown in the national broadcast. Facebook and Twitter were perceived as a 'catalyst' that accelerated the Jasmine Revolution as Marzuki et. al. (2012: 247) believes without this social networking platform, the revolution would certainly have evolved more slowly. The Tunisian revolution was fought not only in the streets but also in the 'cyber-warfare' encompassing the Internet forums, Facebook pages, YouTube channels, Twitter feeds and blogs (Honwana 2011: 8). This cyber activism is generated by young Tunisian bloggers and tech-savvy or technical know-hows, who were using online social networks to reveal regime abuses and disclose government corruptions besides distributing information about the situations involving the mass mobilization and people uprisings. To note here, by March 2011, as reported by the UNHCR, nearly 3.5 million of Tunisians were Internet users. As Howard \& Hussein (2013: 50) demonstrate, after December 17, 2010 particularly when Bouazizi set himself on fire, the Tunisian cyber community experienced a spike in the frequency of online conversations about the revolution and President Ben Ali's leadership. Through this route, the volume of digital conversations peaked with the size of street demonstrations and the content of these conversations directly reflecting public sentiments. The communication of information was vital to the success of this revolution, and Facebook was its main vector, as recognized by many foreign observers (Marzuki et. al. 2012: 238). Before Ben Ali regime collapsed, more than a thousand people were tweeting each day about that political change in Tunisia, an action which led to the people's high determination to materialize a democratic transition. In Tunisia, the cyber-community including Facebookers, Tweeterians and the bloggers anticipated what happened on the ground by the day and the online demands for freedom and liberty eventually manifested themselves in the streets (Howard \& Hussein 2013: 52). There is no doubt why the Tunisian Jasmine Revolution was also dubbed the "Facebook Revolution" or Tweeter Revolution" by the Western media as these communication tools had brought a significant impact, fuelling mass mobilization and a dramatic political transition in the country (Gilad et. al. 2011).

\section{The Case of 2011 Egyptian Revolution}

The 2011 Egyptian uprising, which had truly inspired and resonated from the Tunisian Jasmine Revolution, began with revolt and anti-government protest on January 25, 2011 and was continuing for 18 days which resulted in the collapse of the 30-year rule of Hosni Mubarak's regime on Friday, $11^{\text {th }}$ of February 2011. In a country of 80 million citizens, it was estimated that 18 million Egyptians participated in the revolution which took place in all of Egypt's twenty-seven provinces including Cairo, Alexandria, Suez, Ismailia, Mansoura, Sinai, and several more. Tahrir Square, a major public town square in Downtown Cairo in Egypt was occupied by millions of protesters and made the symbol of liberty and people's power. Egyptian activists call for an uprising, primarily to protest against police brutality, government corruption and power abuse, unemployment, poverty and inequality, and the autocratic rule of Hosni Mubarak, who had been in power since 1981. According to Monem (2012: 21), 18 days throughout the revolution, Egyptians displayed a willingness to pay for something that was regarded as priceless for the sake of political transition and to achieve the popular slogan- "the people want the fall of the regime". Between January 25th and February 16th, 2011, it was estimated that 846 protesters were killed and 6467 were wounded as the repercussion from police's aggression. The regime desperately took on some rougher measures, using riot-control tactics, and shutting down the Internet and all forms of communication in order to weaken the revolution (Bakr 2012: 57). According to Wahba (2011: 2), to undermine the protests, Mubarak promised all activists and protesters that he would not run for another term in the next presidential elections and he had dissolved his government by appointing new figures in the new cabinet and 
called for the constitutional amendments in few articles. However, all these 'appeals' were viewed as a carrot and stick approach rather than genuine fundamental reforms which increased the Egyptians' momentum in the revolution to force his immediate departure. With all pressures exerted domestically and globally, Mubarak finally surrendered to his own people and passed the power down to the Egypt's Supreme Council of the Armed Forces. Unlike Tunisia, Egypt has experienced a number of revolutions which successfully led to a regime change as occurred in 1919 and 1952. And the 2011 revolution, by no doubt, has brought those memories alive after being dormant for a long period and was considered as the most unexpected development in modern Egyptian political history (Sharp 2012: 48). As Storck (2011: 19) has pointed out, although the removal of Mubarak took nearly 3 weeks, the protests movement that dragged him down was a product of a much longer process of buildup and planning, a product of years of dictatorship and repression that had ignited political revolution. The January 25th revolution was seen extraordinary as it was the first time, hundreds of thousands of ordinary and non-activist Egyptians took to the street to demand for the end of the autocratic regime and they successfully met it (Lynch 2011:3).

\section{Timeline of Event: The 25 January-11 February Uprising}

As reported by Aljazeera, the Egyptian revolution or the "Day of Rage" had officially begun on January 25, 2011 when almost 10, 000 protesters gathered in Cairo and thousands more in another major city across Egypt. Three days later, on January 28, so called the "Friday of Anger" the number of protesters had increased by ten times. An estimated 100, 000 Egyptians went to Tahrir Square forcing the resignation of Hosni Mubarak. Clash and heavy confrontations occurred between protesters and riot polices. The regime decided to shut down Internet access and disrupt communication line since social media was widely used to organize the mass mobilization and demonstrations. During this period, Egypt had totally gone into chaos when prisons were broken, which led prisoners to have escaped and some government buildings such as the Ministry of Interior and police station burned (Monem 2012: 23). According to Sharp (2012: 53), on January 30, the military was deployed on the street which gradually brought on a curfew throughout the state. This action however, was unable to stop the march from all over Egypt when the scale of demonstration was unprecedented- a quarter of a million protestors turned out in Tahrir Square on February 1 in response to Mubarak's speech in which he said he would not run for re-election and would pledge for a peaceful power transfer. In the next few days, violence escalated as Mubarak's supporters took offence against revolutionaries in Tahrir Square. It was recognized as a "Battle of Camel" as proMubarak men rode on horses and camels to break the square. After several days of chaos and violence, on Friday February 4, hundreds of thousands of Egyptians again filled Tahrir Square for a peaceful rally. During this time, the army had tightened its control by installing coils of razor wire, limiting media access and erecting checkpoints. As pointed out by Jeremy Sharp, on February 8, protesters significantly expanded their revolt and gained momentum against the regime, sparked by the release of Wael Ghonim which was seen as an earlier success to the revolution. At that moment, the demand for Mubarak's resignation was unstoppable. This event might be seen as the beginning of the end of the Mubarak regime, coupled with international pressure on him to restore peace and normalcy in Egypt, something that was extremely far-reaching if he still remained in the office. Finally, after 18 days of peaceful protest, interspersed with chaos and bloodshed, Mubarak officially resigned on February 11 and left his power to the Egyptian Armed Forces. His resignation began a new era for the Egyptian revolution, for Egyptian politics and for the country at large (Monem 2011: 2).

\section{Major Causes of the 2011 Egyptian Revolution}

Undoubtedly, eighteen days that changed Egypt might come from several contributing factors and the reason behind it as can be seen below. 


\section{Economic Instability}

According to Noha Bakr (2012: 58), the Egyptian economy as a whole was performing better than ever, with its GDP growth increasing from just below 5\% in the mid-1990s to 7\% in 2006-2008. Despite the economic growth, Ali Sarihan argues that many Egyptians lived in poor conditions. As recorded by the CIA World Factbook, the inflation ratio in Egypt was very high in 2010, at 11.1 percent which led to almost 20 percent of Egyptians living under the poverty level (Sarihan 2012: 75). Moreover, the gap between the rich and the poor was so great that it led to the problem of inequality and imbalanced development. Prior to the revolution, the economy grew but this growth did not trickle down, as it only benefited certain classes and regions in the country especially the regime's family members. As Noha Bakr has pointed out, there were areas in the Upper Egypt that were completely alienated from the economic development, leading to the marginalization in the society. Apart from that, the unemployment had reached $9.7 \%$ which was concentrated among youth and graduates. The total number of the unemployed, on the eve of the uprising was about 2.5 million, mainly youth aged 20-24 who constituted the main striking force of the revolution (Korotayev \& Zinkina 2011: 167).

\section{Political Legitimacy}

Noha Bakr (2012: 65-66) who works in the Egyptian Revolution found that the political mood in Egypt prior to the revolt was very cynical and full of bitterness during the 30 years of Mubarak's rule. The political system in Egypt with centralized administration was believed to have insisted in paving the route to hereditary rule when the constitution was amended few times specifically to suit the November 2011 presidential election which was seen to favour Mubarak's son, Gamal Mubarak, thus eliminating any chance of free and fair competition. It was suspected that the results of the last 2010 Parliamentary election, which gave an unprecedented majority win to the ruling party; the National Democratic Party (NDP) was being fraudulent. This election fraud which was also happening in the 2005 legislative election led to the Egyptian expectation that the same agenda will be manifested in the next election. Apart from that, human rights abused by security forces, plus the extreme corruption, by no doubt delegitimized the regime of political power which brought about a feeling of frustration, injustice and humiliation among fellow Egyptians. In addition, as claimed by Monem (2012: 33), the continuous implementation of the emergency laws over the course of 30 years had expanded the power of the police. For many years, the opposition's political activities were constrained and mistreatments to citizens were widespread. As Paciello (2011:3) has pointed out, under the rule of Hosni Mubarak, the political opposition in Egypt was weakened by the implementation of many instruments such as through repressions, harassment, restrictions on the media and press, refusal to legalise parties and electoral manipulation-all these issues inevitably declined Mubarak's political legitimacy and increased the people's anger which manifested through the January 25th Revolution.

\section{Social Demography}

Following La Graffe's (2012: 71) studies, the social demographics factor undeniably played a prominent role, specifically in regard of the role of the Egyptian youth in the 2011 Revolution. From 1980 to 2010, life expectancy in Egypt increased by fifteen years, resulting in a youth bulge in the population. In Egypt, over $54 \%$ of its population were made up by people under 24 years of age and two thirds of Egyptians are under 30 (La Graffe 2012: 72; Bakr 2012: 67). According to Monem (2012: 27), Egyptian youth suffered from major problems in the transition to adulthood: unequal access to education, unemployment, poverty, lack of transportation and housing, long period of 
waiting to form a family, and lack of political participation. As of 2010 the Egyptian unemployment rate was reportedly 9.7 percent, although this did not include the under-employed. Each year, 700, 000 new graduates competed for 200, 000 new jobs which increased the growth rates of the unemployed- leading no hope for the majority of youth in the future (Bakr: 2012). These factors explain why massive youth participated in the revolution against decades of poor governance and failed Institutions and demonstrate how demographic data in general, and the youth bulge in particular, affected the regime change in Egypt.

Islamism

In many respects, Egypt was already a quasi-Islamic state since 1980 when the constitution had identified Islam as the official religion of state, with the Muslim Brotherhood (MB) the largest and most organized opposition group in the country (Noueihed \& Warren 2012: 120). Prior to the uprising, as stressed by Kerckhove (2012) the political future and involvement of the MB was unclear during the January 25 Revolution. Habitually reluctant to confront the regime and its security forces, the Brotherhood did not fully join the protests until it became clear that a mass uprising had taken shape. Throughout the uprising, the MB appeared largely content to participate in, rather than lead, the demonstrations, despite being Egypt's best-organized and the most highprofile opposition group. The MB suggested that it did not want a misinterpretation of the events as "an Islamic revolution" which could fail the effort to overthrow Mubarak's regime (Kerckhove 2012) Moreover, the bad experience being subject to political abuse, frequent harassment, brutality, leadership arrest and confiscation of financial assets by the regime for several years let the MB to remain 'low profile', to be kept moderate and to prefer the non-confrontational approach towards the regime during the revolution (Paciello 2011: 4). Only the members of the youth wing of the MB, participated in the revolution and played a visible role by assisting to defend the protesters against pro-Mubarak supporters during the 'Battle of Camel' (Gelvin 2012: 58; Masoud 2011: 24).

\section{The Advance of New Social Media}

According to Monem (2012: 30), the IT revolution in Egypt has been unprecedented in its scope when 22.6 million Egyptians, mostly youth, already had an Internet access in 2010. To this end, Egypt has been classified as one of the emerging powers in IT. Internet use has also been on the rise in Egypt, in line with the existence of new social media. In 1999, the number of Internet users in Egypt had reached 300, 000 and this figure massively increased in 10 years to 14.5 million in 2009 . Since 2011, Egypt has nearly 8357, 340 Facebook users with 78\% of them are youth between 15-29 years. Meanwhile, the average number of Twitter users in Egypt between January and March 2011 was estimated 1131, 204 (Nadine \& Rabia 2011: 140-141). As pointed out by Hamdy (2009), the substantial access to social media among Egyptians was available mainly because of the regime's efforts to expand the state's IT capabilities to attract major foreign companies and serve as a tool for socioeconomic development. However, this effort becomes a very effective weapon used by protesters to topple the regime in 2011. Following the event of 25th January Revolution, Eltantawy \& Wiest (2011: 1212), demonstrate that social media technologies represent an important instrumental resource that contributed to the birth and sustainability of the protest. This statement was supported by Madeline Storck (2011: 24) as she outlines several roles played by the new social media in contributing to the success of the Egyptian uprising such as the social media as an organizational tool, as an alternative press and as a tool for generating awareness both regionally and internationally. For Egyptians, Facebook and other social media are not simply sites used for entertainment; rather they are also used for political activism and for criticizing public authorities on the issues of corruption, regime forces brutality, government responsibility and so forth (Howard \& Hussain 2013: 56; Abdel Monem 2012: 30). 
What is perhaps most vital about the use of these new social media in the Egyptian uprising as deeply explained by Eltantawy \& Wiest (2011: 1213-1214) is how it changes the dynamics of social mobilization. Social media introduce speed and interactivity that were lacking in the traditional mobilization measures such as through posters and leaflets. It took only less than 30 days to overthrow the 30-year dictatorship in Egypt, suggesting the incredible rate of the political turning point. Central to this acceleration, as pointed out by Storck (2011: 25) was the efficient use of new social media as the Egyptian protesters and activists were able to successfully utilize to their advantage - the social networking capabilities of Twitter and Facebook. Through these media, information can be spread via "many-to-many" communication, thus alerting the majority of the cyber community across Egypt rapidly. These activists have created Facebook groups, Twitter accounts, YouTube videos and personal blogs to engage with all people and supporters in discussions on the current situations in the country, besides helping to generate political awareness and initiating the revolution. For example, the Facebook group of 'We are all Khaled Said' was used to disseminate information on the latest misdeeds of the Mubarak regime, a discussion that has appeared to gain momentum among many frustrated citizens. Obviously, the major advantage of the new social media in the Egyptian revolution was its capacity for swiftly exchanging and disseminating information to millions of people inside and outside of Egypt (Eltantawy \& Wiest 2011: 1213). This cyber activism, as stated by Khamis et al (2011) paved the way for regime change in January 2011 in Egypt by becoming a major trigger for street activism and aiding the mobilization and organization of protests and other possible forms of political expression.

As a conclusion, this article comprehensively revealed the factors that contributed to the 2010-2011 Arab Spring events, manifested by the Tunisian and Egyptian revolution other than describing the background and timeline of the events. The issues of economic development and political legitimacy as well as the nature of social demography were identified as three common factors which caused the regime change in the Arab Spring while the insignificant role of Islamist organizations during the revolutions successfully led to the political transition in Egypt and Tunisia. This article also argued that although there were common elements during the Arab Spring protests, there was some uniqueness with the recent uprising in Tunisia and Egypt. The emergence of new social media such as facebook and twitter played a crucial role as it helped the protesters to organize and mobilize the mass protest more effectively, generates political awareness among citizens more widely and frequently inspire people to be more responsible on the issues of politics, social and economy in the country.

\section{References}

Achy, L. 2011. The Carnegie Papers: Tunisia's Economic Challenge. Washington: Carnegie Middle East Center.

Alexander, C. 2011. Tunisia's protest wave: where it comes from and what it means. Foreign Policy. http://foreignpolicy.com/2011/01/03/tunisias-protest-wave-where-it-comes-from-andwhat-it-means/ .Retrieved: 20 August 2014.

Arieff, A. 2012. Political transition in Tunisia. In, De Leon, J.C \& Jones, C.R. (ed.). Tunisia and Egypt: Unrest and Revolution (pp 1-43). New York: Nova Science.

Ayadi, R. Et. al. 2011. The Tunisian Revolution: An Opportunity for Democratic Transition. Rome: Instituto Affari Internazionali.

Bakr, N. 2012. The Egyptian Revolution. Accessed online via http://www.um. edu.mt/data/assets/pdffile/0004/150394/Chapter4-Noha_Bakr.pdf. Retrieved on 17th June 2013.

Bishara, A. 2011. The Great Popular Tunisian Revolution. Doha: Arab Center for Research \& Policy Studies.

Chang, R. 2012. Addressing unemployment. In, Hopmann, P.T \& Zartmann, I.W (ed.). 2012. Tunisia: Understanding Conflict 2012. Baltimore: School for Advance International Studies, John Hopkins University. 
Driss, A. 2011. Thoughts on the Tunisian Revolution. Madrid: Elcano Royal Institute.

Driss, A. 2012. The Revolution in Tunisia-an Opportunity for a Real Change. www.um.edu.mt/data/assets/pdf/Chapter_2-Ahmed_Driss.pdf. Retrieved 14th June 2013 .

El Gody, A. 2007. New Media, new audience, new topics, and new forms of censorship in the Middle East. In, Seib, Philip. ed. New Media and the New Middle East. (pp. 213-234) Hampshire: Palgrave Macmillan.

El May, M. 2012. The Jasmine Revolution. Turkish Policy Quarterly. 9 (4): 55-61.

Eltantawy, N. \& Wiest, J.B. 2011. Social media in the Egyptian revolution: reconsidering resource mobilization theory. International Journal of Communication. 5: 1207-1224.

Gelvin, J. L. 2012. The Arab Uprisings: What Everyone Needs to Know. Oxford: Oxford University Press.

Hamdy. 2009. Arab Citizen Journalism in Action: Challenging Mainstream Media Authorities and Media Laws. Westminster Papers in Communication and Culture. (University of Westminister, London). 6 (1): 92-112.

Honwana, A. 2011. Conflict Prevention and Peace Forum: Youth and the Tunisian Revolution. New York: Social Science Research Council.

Howard, P. N \& Hussain, M.M. 2013. Democracy's Fourth Wave? Digital Media and the ArabSpring. Oxford: Oxford University Press.

Kerckhove, F.D. 2012. Egypt's Muslim Brotherhood and the Arab Spring. Canadian Defence and Foreign Affairs Institute. Policy Update Paper.

Khamis, S. et al. 2011. Beyond Egypt's "Facebook Revolution" and Syria's "YouTube Uprising" Comparing Political Contexts, Actors and Communication Strategies. Maryland: University of Maryland.

Koplow, M. 2011. Why Tunisia's Revolution Is Islamist-Free And how their absence explains the quick fall of Ben Ali's regime. Foreign Policy. http://foreignpolicy.com/2011/01/14/whytunisias-revolution-is-islamist-free-2/. Retrieved: 20 August 2014.

Korotayev, A.V \& Zinkina, J.V. 2011. Egyptian revolution: a demographic structural analysis. Entelequia Revista Interdisciplinar. 13: 139-169.

Korotayev, A.V \& Zinkina, J.V. 2011. Egyptian revolution: a demographic structural analysis. Entelequia Revista Interdisciplinar. 13: 139-169.

Lynch, M. et al. (ed.). 2011. Revolution In the Arab World: Tunisia, Egypt, And The Unmaking of An Era. Washington, D.C.: Slate Group.

Machado, C. 2012. Internal security and reform. In, Tunisia in Hopmann, P.T \& Zartmann, I.W (ed.). Tunisia: Understanding Conflict 2012. Baltimore: School for Advance International Studies, John Hopkins University.

Marzuki, Y. et al. 2012. The Contribution of Facebook to the 2011 Tunisian revolution: a psychological insight. Cyberpsychology, Behaviour and Social Networking. 15 (5): 237-244.

Moaddel, M. 2012. The Arab Spring and Egyptian Revolution Makers: Predictors of Participation. Population Studies Center Research Report 12-775. Michigan: Eastern Michigan University.

Monem, A.S. 2011. The Paradox of The Egyptian Revolution. Middle East Brief. 55: 2-7.

Monem, A.S. 2012. State and Revolution in Egypt: The Paradox of Change and Politics. Massachusetts: Crown Center for Middle East Studies, Brandies University.

Nadine, K.C. \& Rabia, M.S. 2011. The reasons social media contributed to the 2011 egyptian revolution. International Journal of Business Research and Management (IJBRM). 2 (3):139154.

National Lawyers Guild et. al. (2012). Promises and Challenges: The Tunisian Revolution of 20102012. New York: National Lawyers Guild.

Noueihed, L \& Warren, A. 2012. The Battle For The Arab Spring: Revolution, Counter-Revolution and The Making of a New Era. New Haven: Yale University Press.

Paciello, M.C. 2011. Egypt: Changes and Challenges of Political Transition. Mediterranean Prospects Technical Report. European Commission's Seventh Framework Research Programme.

Sarihan, Ali. 2012. Is the Arab spring in the third wave of democratization? the case of Syria and Egypt. Turkish Journal of Politics. 3 (1): 67-83. 
Sharp, J.M. 2012. Egypt: The January 25 revolution and implications for US foreign policy in De Leon, J.C \& Jones, C.R. (ed.). Tunisia and Egypt: Unrest and Revolution. New York: Nova Science. pp. 46-97.

Storck, M. 2011. The Role of Social Media in Political Mobilisation: A Case Study of January 2011 Egyptian Uprising. Master Thesis, University of St. Andrews.

Tsai, T. 2012. Understanding unemployment in Tunisia. In, Hopmann, P.T \& Zartmann, I.W (ed.). Tunisia: Understanding Conflict 2012. Baltimore: School for Advance International Studies, John Hopkins University.

Wahba, K. 2011. The Fall of the Virtual Wall -The Revolution Systems Thinking Archetype. 29th International System Dynamics Conference, Washington, DC, USA. 